\title{
トキソプラズマ性耳下腺内リンパ節炎例
}

\author{
川畑 隆之・鳥原 康治*・直野 秀和 \\ 松田 圭二・河野 浩万 ・東野 哲也
}

\section{Case Report: Toxoplasmic Intraparotid Lymphadenitis}

\author{
Takayuki Kawabata, Hidekazu Naono, Keiji Matsuda, \\ Hirokazu Kawano and Tetsuya Tono \\ (Miyazaki University)
}

Koji Torihara

(Miyazaki Prefectural Hospital of Miyazaki)

\begin{abstract}
Toxoplasmosis usually manifests as a cervicofacial lymphadenopathy in adults, and its manifestation as a parotid mass is very rare. In this article, we present the case of a 48-year-old with acquired intraglandular parotid toxoplasmosis which clinically mimicked a parotid gland tumor. We performed superficial parotidectomy, suspecting a malignant tumor. However, the postoperative histopathology, indicated toxoplasmic lymphadenitis. Serological tests revealed high levels of both IgM and IgG antibodies against Toxoplasma in the serum. We concluded that the disease was due to active infection with Toxoplasma gondii. Through the postoperative administration of specific antibiotic agents, the patient remained symptomatically well without signs of systemic or local toxoplasmosis. The infection was believed to have been transmitted via the patient's pet rabbit.
\end{abstract}

Key words : Toxoplasma, lymphadenitis, parotid, rabbit

はじめに

トキソプラズマ症は細胞内寄生原虫であるToxoplasma gondii による感染症で, ヒトだけではなく鳥類, 哺乳類 に感染がみられる人畜共通感染症である. トキソプラズ マ症は先天性と後天性の 2 つ大別され, 先天性トキy プラズマ症は妊婦の感染による小児への経胎盤感染が原 因である. 流産, 死産による胎児死亡, 出生後の水頭症, 網脈絡膜炎, 脳内石灰化などは予後不良症例である。一 方, 後天性トキソプラズマ症は多くの場合は不顕性感染 で, 筋肉, 脳などの全身臓器に囊子を形成し, 感染を終 生継続する．経口摂取した原虫のオーシストの急性分裂
による発熱, リンパ節腫大などの急性症状のほか, AIDS などでの宿主免疫能低下によるトキソプラズマ性日和見 感染む重篤な全身症状を呈する感染症として重要であ る. 耳鼻咽喉科領域ではトキソプラズマ性頸部リンパ節 炎がよく知られており，頸部のリンパ節腫脹の鑑別疾患 として念頭に置いておくべき疾患である. 今回，われわ れは耳下腺腫瘍と診断し手術したが，耳下部卜キソプラ ズマ性リンパ節炎であった珍しい症例を経験したので報 告する. 


\section{症例}

患者：48歳，女性.

主訴：右耳下部腫脹。

現病歷:平成 17 年 6 月頃より右耳下部に腫瘤を自覚す るも放置していた。腫瘤は消退せず全身倦怠感もあるた め, 7 月 9 日, 近医耳鼻咽喉科索受診。右耳下腺腫瘍疑 いの診断で精查目的のため，7月 12 日，当院紹介受診と なった。

既往歴：平成 5 年，近医外科にて右鎖骨上の腫瘤摘出 術（詳細不明）。

平成 13 年，当院皮膚科にて右後頸部脂肪腫摘出術.

生活歴：ウサギ飼育歴あり（平成 15 年頃〜平成 17 年
2 月まで), 猫飼育歴なし，生肉食歴なし，

局所所見：右耳下部に $2.5 \times 1.0 \mathrm{~cm}$ ，境界明瞭で圧痛 のない腫瘤を触知した。可動性は良好で, 皮虚との癒着 は認めなかった。また左副神経リンパ節領域に軽度の圧 痛を伴う $1.5 \mathrm{~cm}$ 大のリンパ節を1個触知した。

全身所見：発熱などは認めなかった。

検查所見 :

〈1〉血液検查：WBC $5600 / \mu \mathrm{L}$ （基準值 $4000 ＼mathrm{~ 9000 ）, ~}$ $\mathrm{CRP} 0.0 \mathrm{mg} / \mathrm{dL}$ (基準值 $0.0 \sim 0.3$ ） と炎症所見を認めず, 肝機能も GOT 23 IU/L (基準值 13〜23) GPT 25 IU/L (基 準値 6 ～27）と正常範囲内であったが，アミラーゼは 172 IU/L（基準値 45 ～130）と軽度上昇していた.

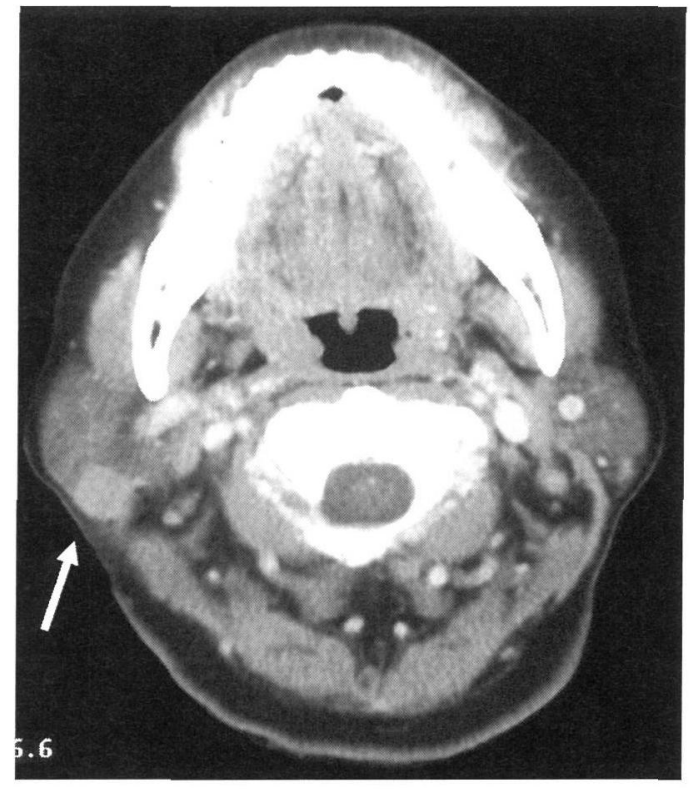

A

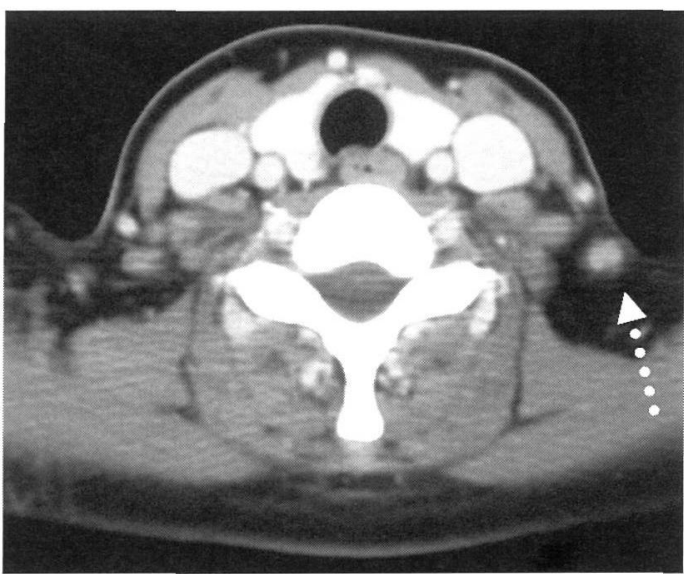

C

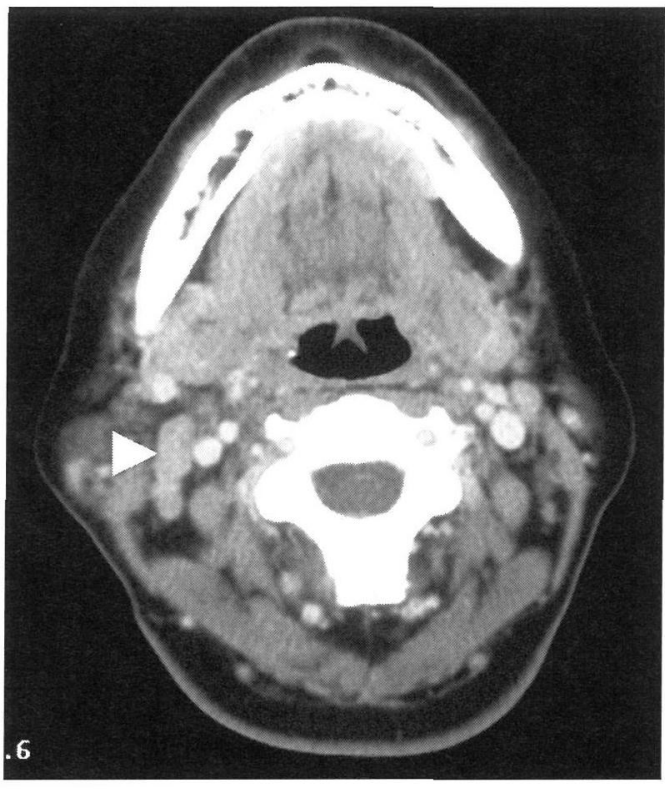

B

図 1 術前造影 $\mathrm{CT}$ 検査

$\mathrm{A}$ : 右耳下腺下極に造影剂にて均一に造影される比較的 境界明睹な円形の腫瘤を認める（矢印）。

$\mathrm{B}$ ：右上内深頸リンパ節領域に複数のリンパ節腫大を認 める (矢頭)。

C : 左副神経領域に 1 個の腫大したリンパ節を認める (点線矢印). 


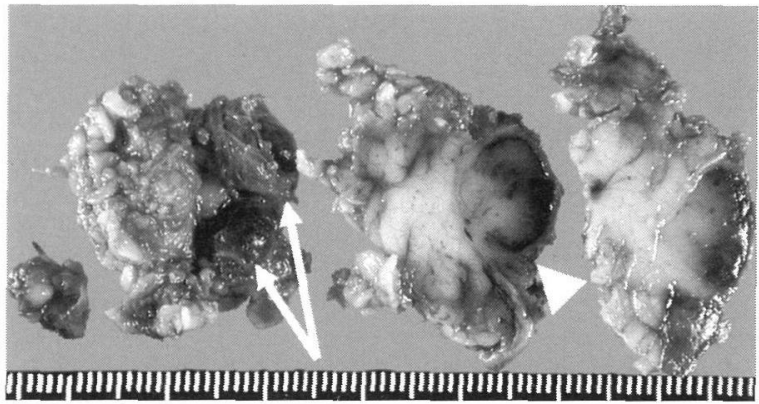

図 2 摘出標本

耳下腺浅葉内に暗赤色の球形の腫瘤を 2 個認めた (矢印 2 本）。また割面像では境界は被膜で保持されている（矢 頭).

〈2〉造影 CT : 右耳下腺下極に直径 $13 \mathrm{~mm}$ の造影剂に て内部が均一に造影される境界明瞭な円形腫瘤を認め た。さらに右上内深頸リンパ節領域には多発性の, 左副 神経リンパ節領域には孤立性のリンパ節腫大が認めら れ，いずれも内部均一に造影されていた（図 1)。

$\langle 3\rangle$ 穿刺吸引細胞診（FNAB）：脂肪とともに正常の耳 下腺腺房細胞と導管細胞を認めるのみであった。

治療・経過：術前検查にて悪性所見は得られなかった が，完全な否定もできないため，右耳下腺悪性腫瘍，両 頸部リンパ節転移を念頭に置き，8月 22 日，右耳下腺浅 葉部分切除術を施行した。耳下腺浅葉内に暗赤色球形の 腫瘤を 2 個下極に腫大したリンパ節を 1 個認めたため, 同時に摘出し病理学的検査に供した（図 2). 病理組織学
的診断は反応性リンパ節症で，リンパ節内に類上皮細胞 の集簇による肉芽腫形成を認めた（図 3)。この結果より トキソプラズマ症が疑われ，8月 22 日，トキソプラズマ 抗体を測定したところ， IgM が $2.6 \mathrm{IU} / \mathrm{mL}$ (基準值 0.8 未満), IgG が $223 \mathrm{IU} / \mathrm{mL}$ (基準值 6 未満) と高值を示し, トキソプラズマ性リンパ節炎と確定診断した（図 4)。頸 部に多数の反応性リンパ節腫大を認め, 全身倦念感も あったことから9月5 日よりサルファダイアジン・ピリ メタミン合剤 $1000 \mathrm{mg} /$ 日の内服を開始した。9月 22 日 の血液検查で肝機能障害が出現したため内服を中止した が，その頃より頸部リンパ節が急速に縮小し，その後， 平成 19 年 6 月現在まで明らかなリンパ節再腫大などは認 めていない.

\section{考察}

トキソプラズマ症の罹患率は年齢 $\times 0.1 \sim 1 \%{ }^{11}$ ，健常 人の抗体保有率は 10 ～15\% ${ }^{2)}$ と決して少なくない. 九州 地方などの温暖な地域で多くみられ，後天性のもののほ とんどが不顕性感染で経過する。顕性感染では表 13) の ような所見が挙げられるが，本症特有の所見はない。症 状の差異は, 原虫の病原性や, 毒性, 原虫に刘する宿主 免疫応答の差によるといわ扎ている4). また後天性の卜 キソプラズマ症では図 55)のよらな生活史がみられ, ヒ トへの感染経路は, 猫の糞便加のオーシストを経口的 に摂取する，むしくは豚，子羊などの生肉，十分加熱処 理のされていない食肉内のシストを摂取することによ

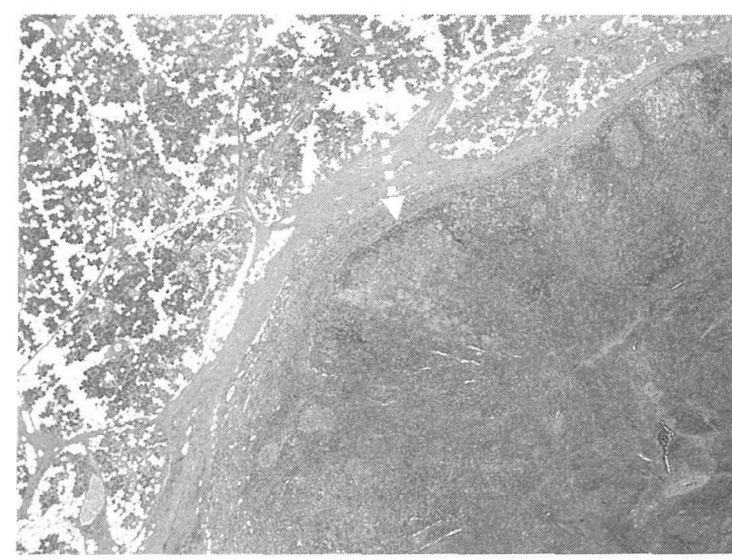

A

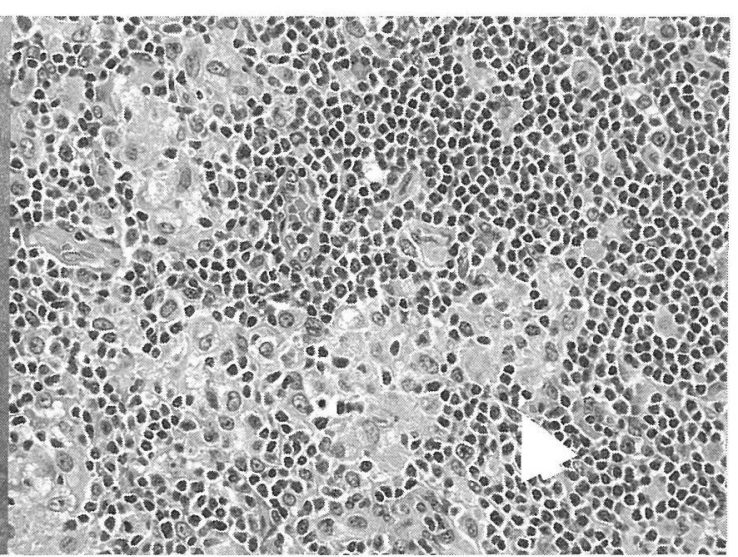

B

図 3 病理検查所見 (HE 染色, A : × 10 倍 B : × 100 倍)

$\mathrm{A}$ ：胚中心などのリンパ節構造は保たれ正常耳下腺組織とは明瞭に区別される.

B ：リンパ節構造内に多数の好酸性の類上皮細胞の小集簇が散在している. 

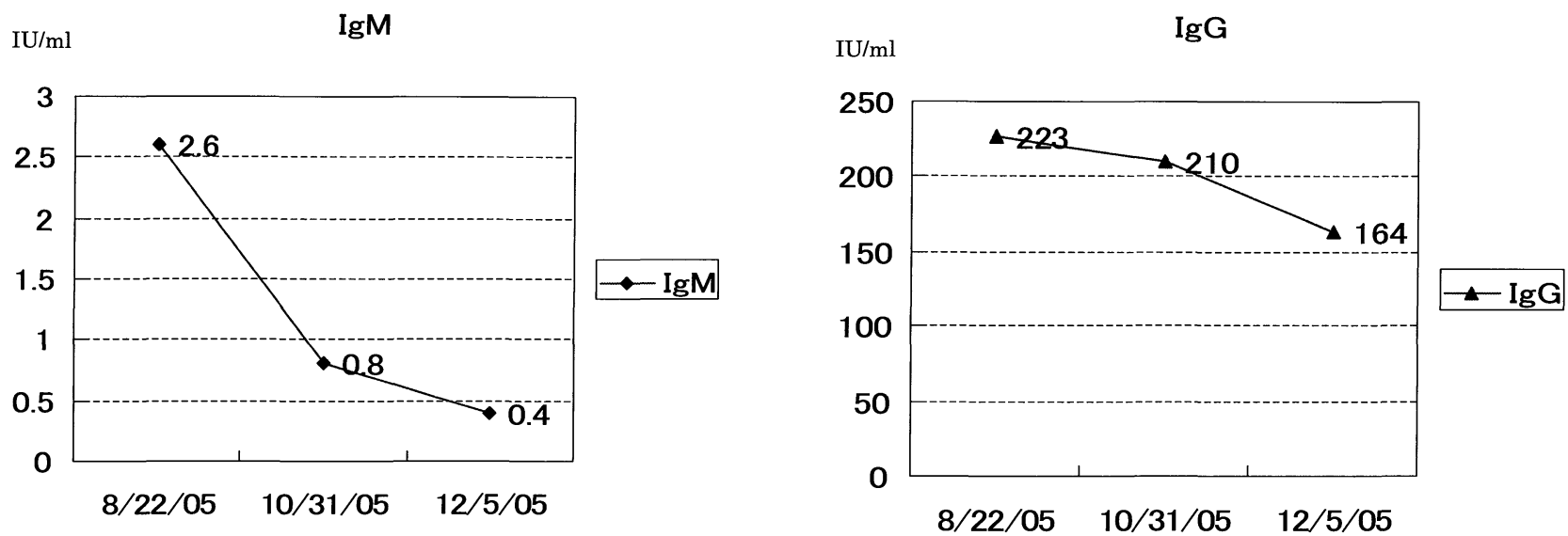

図 4 トキソプラズマ抗体の推移

トキソプラズマ IgM 抗体は 2.6 と上昇しており，急性感染が示唆された．その 2 月後には正常範囲内に消退した. トキソプズ

マ IgG 抗体は高值を示し 3 カ月経過してやや消退傾向あるも持続した.

表 1 後天性トキソプラズマ症

\begin{tabular}{|c|c|c|}
\hline 疫 & 学 & $\begin{array}{l}\text { 九州地方などの温暖な地域 } \\
10 \text { 歳〜 } 20 \text { 歳代の比較的若い女性 }\end{array}$ \\
\hline 症 & 状 & 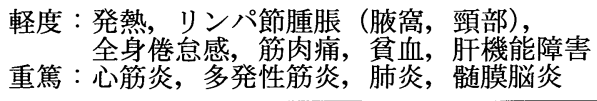 \\
\hline & & 特異所見なし \\
\hline
\end{tabular}

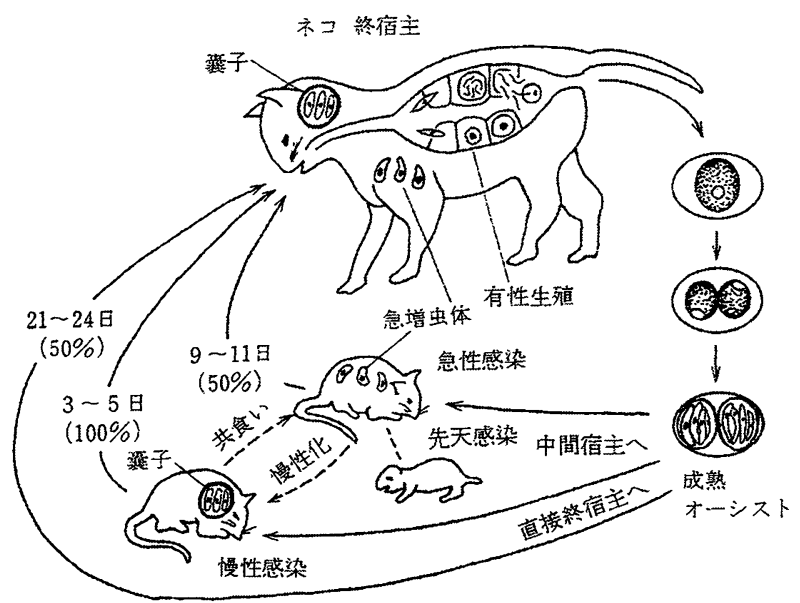

図 5 トキソプラズマ感染症の生活史

吉田幸雄著 : 図説人体寄生虫学 : 南山堂より引用5)

る. 頻度としては後者が多く, 経口摂取後 24 時間以内に 血行性に全身に伝播され, 生理学的にトラップされやす い中枢神経系や胎盤, 心臓, 腎臓, 横紋筋などに生着し そこで寄生する ${ }^{1)}$. 当症例では猫飼育歴はないが近所に
表 2 トキソプズマ症の検査方法

\begin{tabular}{|c|c|c|}
\hline 診断 & & \\
\hline \multirow{3}{*}{ 直接診断 } & マウス接種法 & $\begin{array}{l}\text { マウスの腹腔内にリンパ節の磨砕 } \\
\text { 乳化物の摂取により増殖した原路 } \\
\text { の同定 }\end{array}$ \\
\hline & PCR & $\begin{array}{l}\text { トキソプラズマ原虫遺伝子 } \\
\text { (SAG1) の同定 }\end{array}$ \\
\hline & 塗抹検査 & $\begin{array}{l}\text { Papanicolau 染色による囊子の検出 } \\
\text { Wright-Giemsa 染色のよるタキゾ } \\
\text { イド, 偽袈子の検出 }\end{array}$ \\
\hline \multirow[t]{2}{*}{ 間接診断 } & $\begin{array}{l}\text { 色素試験（D } \\
\text { 間接赤血球凝 } \\
\text { 補体結合反氾 } \\
\text { ラテックス凝 } \\
\text { ラテ間接蛍光抗体 } \\
\text { 酵素抗体法 }\end{array}$ & $\begin{array}{l}\text { ）応（IHA） } \\
\text { (CF） } \\
\text { 契反応（LA） } \\
\text { 去（IFA） } \\
\text { LISA） }\end{array}$ \\
\hline & \multicolumn{2}{|l|}{ 病理検査 } \\
\hline
\end{tabular}

野良猫がいたこと，加熱処理の不十分な食肉を嗜好しな いこと，ウサギをペットとして飼育しており糞の処理は 患者が主に行っていたことなどから，猫から土壌中に排 出されたオーシストをウサギが摂取して感染し，その粪 として排出されたオーシストを経口的に患者が摂取し た可能性が高い. ウサギ自身は現在死亡しておりトキソ プラズマ抗体测定による確定診断は困難だが， Ishikawa ら6) の報告でもウサギを介した頸部トキソプラズマ性リ ンパ節炎が報告されていることから，猫だけでなく他の 動物の飼育歴も十分に問診することが重要と考えら れる。 また表 2 のような検査方法が用いられ, 最近では 
Zaharopoulos ${ }^{7)}$ が FNAB にて確診できたと報告している が，必ずしも適切な標本が採取できるとは限らず，トキ ソプラズマの検出は容易でない，木村ら ${ }^{8)}$ は生検リンパ 節よりトキソプラズマ原虫遺伝子（SAG1）を同定でき， 迅速かつ特異的なことから診断に有用であったと報告し ており，今後広く普及することが望まれる．しかし臨床 現場では血清学的, 病理組織学的検查が中心となる. 血 清学的診断は, トキソプラズマ原虫が細胞内に寄生して 細胞の膜表面に抗原を呈示するため, 生存する限り特異 抗体が産生されることによる ${ }^{9}$. 色素試験は高い信頼性 を持つものの生鮮虫体を必要とし, 一般の医療施設での 実施は困難である．IHA，LA，ELISA など簡易キットが 市販されているので，これらを用いて IgM，IgG 抗体を 測定する方が一般的である。本症では好酸球む時に上昇 し，血清学的にも IgE 抗体の上昇が，IgM 抗体の上昇よ りも早くからみられる ${ }^{10)}$. また，伝染性単核球症との鑑 別のために EBV 抗体測定も必要である. 当症例では市 中病院に導入されているトキソプラズマ IgM, IgG 抗体 測定キットを用いて測定したところ，上記のように急性 感染の診断に至ったが, IgE, EBV抗体は測定していない.

病理組織学的にトキソプラズマ症は Piringer 型リンパ 節炎とも呼ばれ，リンパ節の構造は保たれ，壊死，線維 化を認めない.リンパ洞内に未熟な組織球の増殖や, 胚 中心内に多量の蒼白な好酸性細胞質をもった類上皮細胞 の小集簇を認めるのが特徵10) とされるが，本症例も同様 の病理像を得た。

内臟疾患をきたした場合や, 症状が激しいものでない 限り, 免疫能の十分な患者は治療を必要としない, 新生 児, 妊婦, 免疫能の低下した日和見感染の患者には, ピ リメタミン（成人では $25 \sim 100 \mathrm{mg}$ /日を $3 \sim 4$ 週間, 小 児では最初に $2 \mathrm{mg} / \mathrm{kg} /$ 日を 3 日間, 次に $1 \mathrm{mg} / \mathrm{kg} /$ 日から 最上限 $25 \mathrm{mg} /$ 日を 4 週間）とサルファダイアジン（成人 で $4 \sim 6 \mathrm{~g} /$ 日，小児で $100 \sim 200 \mathrm{mg} / \mathrm{kg}$ /日を分割投与）の 併用投与を行う。骨髄抑制予防のためロイコボリン筋注 も併用することが望ましい. AIDS 患者では再発がある ため治療は無期限に行うとされている. サルファダイア ジンを使用できない患者は高投与量のピリメタミン単 独, またはピリメタミン十クリンダマイシン $(1.8 \sim 2.4 \mathrm{~g} /$ 日を分割投与）の投与を行う. 当症例はリンパ節が多発 していたことと, 全身倦怠感が強く食欲低下などの全身 症状があったことからサルファダイアジン・ピリメタミ ン合剤の内服を開始した. その後ロイコボリンの投与は
行っていないにもかかわらず骨髄抑制はみられなかった が, 肝機能障害が出現したため 1 週間で中止した. しか しその頃より左頸部リンパ節腫脹が消腿し, その後も症 状がなかったため自然退縮していた可能性も否定できな い. 過去の文献では, 診断後に内服治療を必要とするも のもあるが ${ }^{11}$, 無治療なまま消退し再燃がないことも多 く, 内服治療の効果は不明で, 頭頸部領域のトキソプラ ズマ性リンパ節炎に対する治療は眼症状や脳症状などが ない限り, 無治療で経過観察して構わないと思われる.

耳下部に発生したトキソプラズマ性リンパ節炎はわれ われが涉猟しえた文献は過去に国内では 1 例12), 世界的 にも 7 例と非常に少ない. 通常 CT では特異的な所見は なく, Warthin's tumor とよく似ており ${ }^{13)}$, 造影剤により 強調される mass として報告され ${ }^{14)}$, 内部に low density を伴うものや伴わないもの，石灰化を伴うものなどさま ざまで, Akan ら 13) も特異的な画像所見はないと報告し ている. そのため耳下腺腫瘍と診断され，耳下腺部分切 除術後の病理にて反応性リンパ節炎が分かり，血清学的 検索を行いトキソプラズマ症と判断されるケースが多 い. 海外では Langford ら ${ }^{15)}$ が穿刺吸引細胞診 (FNAB) を術前に行い, トキソプラズマ原虫を塗抹標本で検出し， 手術を回避できた症例を, Laubert ${ }^{16)} ら か ゙$ 同じく FNABで 反応性リンパ節炎との診断を得, 血清学的にトキソプラ ズマ症を証明し，手術を回避した例を報告している。し かし上述のように CT での所見, FNAB の正診率を考慮 すると，それのみで判断することは困難と考える．過去 の文献むわれわれの症例と同じく, 耳下部のみならず後 頸部や後頭部，顎下部にリンパ節腫大が多発しており， 生活歴聴取や，血清学的検查を行い総合的に判断するこ とが肝要であろう.解剖学的に耳下腺内は $2 \sim 30$ の腺内 リンパ節があるといわれ ${ }^{17)}$, Seifert ら ${ }^{18)}$ は, 8070 人の 唾液腺疾患の患者中 399 人が耳下腺むしくは顎下腺部リ ンパ節炎患者であり,そのらちの 16 人がトキソプラズマ 性リンパ節炎であったと報告している.一方, Byrne ら ${ }^{19)}$ は231 名の耳下腺腫鈞の患者を retrospective に検討した が，トキソプラズマ症患者は認めなかったと報告してお り，唾液腺領域では頻度が少ない，唾液腺腫瘍に頸部り ンパ節腫大を伴うものには, FNAB, Weight-Giemsa 染色 などの塗抹検查による寄生虫検索と血清学的検查を行う ことにより，不必要な手術をせずに診断と治療が可能な 症例むあることを念頭に置くことが重要と思われた。 


\section{まとめ}

1. 耳下部トキソプラズマ性リンパ節炎という珍しい 症例を経験した。

2. ウサギを介したヒトへの感染が予想された.

3. 耳下腺腫瘍と炎症性耳下部リンパ節腫大の鑑別は 困難だが十分な問診, FNAB, 血清学的検查を行えば耳 下腺手術は回避できたかもしれないと思われた。

4. 耳下腺内腫瘤にはトキソプラズマ感染症もあるこ とを念頭に置くべきである.

\section{謝 辞}

本論文寄稿に際し御教示頂いた宮崎県立延岡病院病理部石原 明先生に深謝いたします.

本論文の要旨は第 69 回耳鼻咽喉科臨床学会（2007 年 7 月 6 日, 東京都) において発表した。

\section{参考文献}

1）矢野明彦：トキソプラズマ症. 臨病理 （増） $108: 204$ 209, 1998,

2）前田卓哉:トキソプラズマ症:化療の領域 $22: 38 \sim 42,2006$.

3）竹内裕美：トキソプラズマと耳鼻咽喉科. 耳鼻・頭頸外科 (増) $72: 207 \sim 210,2000$.

4) Mack DG, Johnson JJ, Roberts F, et al. : HLA-class II genes modify outcome of Toxoplasma gondii infection. Int J Parasitol $29: 1351 \sim 1358,1999$.

5）吉田幸雄 : 第 14 項トキソプラズマ [A] 基礎, 図説人体 寄生虫学. $36 \sim 37$ 頁, 南山堂, 東京, 1998 .

6) Ishikawa $T$, Nishino $H$, Ohara $M$, et al. : The identification of a rabbit-transmitted cervical toxoplasmosis mimicking malignant lymphoma. Am J Clin Pathol $94: 107 \sim 110,1990$.

7) Zaharopoulos $P$ : Demonstration of parasites in toxoplasma lymphadenitis by fine-needle aspiration cytology: report of two cases. Diagn Cytopathol $22: 11 \sim 15,2000$.

8）木村美奈子, 鹿間幸弘, 林 朋博, 他: 生検リンパ節組織 よりトキソプラズマ原虫特異遺伝子（SAG1）を証明しえた 後天性トキソプラズマ症の1例. 内科 87:1012 1014, 2001.
9) Moran WJ, Tom DW, King GD, et al. : Toxoplasmosis lymphadenitis occurring in a parotid gland. Otolaryngol Head Neck Surg $94: 237 \sim 240,1986$.

10) Shashy RG, Pinheiro D and Olsen KD : Toxoplasmosis lymphadenitis presenting as a parotid mass: a report of 2 cases. Ear Nose Throat J $85: 666 \sim 668,2006$.

11）脇坂尚宏，吉崎智一，古川 仞：トキソプラズマ性リンパ 節炎例. 耳鼻臨床 $98: 233 \sim 237,2005$.

12）今本千衣子, 大崎能伸, 坂井英一, 他 : 耳下部腫瘤を伴っ たトキソプラズマ症の 1 例. 日内会誌 78: $104 \sim 105,1988$.

13) Akan $\mathrm{H}$ and Akyar S : CT findings in unusual inflammatory masses of the parotid gland. Report of four cases. Eur J Radiol $16: 112 \sim 114,1993$.

14) Akiner MN, Saatci MR, Yilmaz O, et al. : Intraglandular toxoplasmosis lymphadenitis of the parotid gland. J Laryngol Otol $105: 860 \sim 862,1991$.

15) Langford RJ and Whear NM : Serology should be a routine investigation when presented with a major salivary gland lump. Br J Oral Maxillofac Surg $38: 158 \sim$ 159, 2000.

16) Laubert A, Laszig $R$ and Flik $J$ : Differential diagnosis of parotid tumors: toxoplasmosis lymphadenitis of the parotid gland. HNO $37: 432 \sim 437,1989$.

17) McKean ME, Lee $K$ and McGregor IA : The distribution of lymph nodes in and around the parotid gland: an anatomical study. Br J Plast Surg $38: 1 \sim 5,1985$.

18) Seifert G, Miehlke A and Haubrich J : Lymph node disease of the salivary glands. Diseases of the salivary glands. pp $302 \sim$ 303, Thieme, New York, 1986.

19) Byrne MN and Spector JG : Parotid masses: evaluation, analysis, and current management. Laryngoscope $98: 99 \sim 105$, 1988.

原稿受付：平成20年10月 5 日

原稿採択：平成 20 年 4 月 4 日

別刷請求先：川畑隆之

干889-1692 宮崎県宮崎郡清武町大字木原5200 宮崎大学医学部感覚運動講座耳鼻咽喉・頭頸部外科学 教室 